\title{
Valued and received forms of support among Swedish working carers of older people: A descriptive study with focus on ICT-mediated support
}

\author{
Stefan Andersson ${ }^{\mathrm{a}, *}$, Kevin McKee ${ }^{\mathrm{b}}$, Lennart Magnusson ${ }^{\mathrm{a}}$, Christen Erlingsson ${ }^{\mathrm{a}}$ and Elizabeth Hanson ${ }^{\mathrm{a}}$ \\ ${ }^{a}$ Department of Health and Caring Sciences, Linnaeus University, Kalmar, Sweden \\ ${ }^{\mathrm{b}}$ School of Education, Health and Social Studies, Dalarna University, Falun, Sweden
}

\begin{abstract}
.
BACKGROUND: Working family carers are an important resource for the care of older people but can experience negative pressures without support.

OBJECTIVE: This study examined the perceived value of forms of support and the level of receipt of valued forms of support among Swedish working carers, with a focus on information and communication technology (ICT)-mediated support.

METHODS: A convenience sample $(N=129)$ of working carers caring for an older ( $\geqslant 65$ years) relative completed a webbased questionnaire that addressed: caring characteristics; work-care conflict; and valued and received forms of support.

RESULTS: Overall non-ICT forms of support were the most highly valued, while receipt of valued support was low: on average only $16.9 \%$ of participants who valued ICT-mediated forms of support received such support, while the figure was only slightly higher (23.4\%) for non-ICT forms of support. Higher levels of work-care conflict were associated with higher perceived value of support for 13 out of fourteen forms of support.

CONCLUSIONS: The findings suggest that ICT-mediated and non-ICT forms of support should be regarded as complementary, while the low level of receipt of valued forms of support could indicate high levels of unmet need in working carers. Implications for further research and policy on working carers are considered.
\end{abstract}

Keywords: Information and communication technology, family carer support, working carers, work-care conflict, older people

\section{Introduction}

In Sweden, as in most European countries, working family carers (i.e., family members providing unpaid informal care while also working in paid employment/work or as self-employed, hereafter referred to as working carers) play a pivotal role in caring for older people in the community [1]. Due to population ageing and the reduction in welfare provision, working carers'

*Corresponding author: Stefan Andersson, Faculty of Health and Life Sciences, Linnaeus University, Norra Kajplan 6, SE-391 82 Kalmar, Sweden. E-mail: stefan.andersson@1nu.se. contribution to the care of older people is likely to become even more important in the future [2]. However, working carers face significant challenges in balancing and maintaining the roles of worker and carer. To date there has been little research that has focused on the forms of support that working carers find valuable. In particular, with increasing emphasis being placed on the potential of information and communication technologies (ICTs) to support carers of older people [3], more information is needed regarding the perceived value of such ICT-mediated support among working carers in order to enhance their design and implementation. This paper reports a study of the perceived value

ISSN 1055-4181/19/\$35.00 (C) 2019 - IOS Press and the authors. All rights reserved

This article is published online with Open Access and distributed under the terms of the Creative Commons Attribution Non-Commercial License (CC BY-NC 4.0). 
of various forms of support among Swedish working carers of older people, with a focus on ICT-mediated support.

\subsection{Work and care}

About 70\% (900 000) of Swedish carers are in work [4]. The largest group of working carers are middle-aged adults that regularly provide care for a family member, about $80 \%$ of whom are an older family member, most often a parent [5]. Both women and men provide care, while women provide the most demanding care and experience more difficulties to focus on their job [6].

It is acknowledged that working carers can gain satisfaction from providing care, which can sustain them in their role [7]. Satisfaction can arise from the relationship with the care recipient, from feeling appreciated and supported as a carer, and from a sense of accomplishment $[8,9]$. However, most research has focused on the negative impact of the challenges arising from providing care [10], such as high levels of dependency and behavioural disturbance in the care recipient that can cause work interruptions, and restrictions on the carer's social life, leading to a reduction in his or her psychological wellbeing [8,9]. A negative impact can also be related to the strain arising from the combination of care and work obligations. For example, providing care can impact on work performance, and work-related pressures can interfere with the provision of care commensurate with a spillovercrossover effect $[10,11]$. However, working carers may equally value their work as it provides social contact and support, a form of respite from caring and opportunity for self-realisation and independence [10]. The complexity of work-care reconciliation with fluctuating care needs and varying forms and levels of support can make achieving a work-care balance more difficult. This can potentially be detrimental to working carers' mental and physical health [12] and may lead to financial insecurity and loss of pension benefits [13]. While giving up work to provide care is not an option for many Swedish carers, $10 \%$ reduce their working hours to care for an older family member while some $5 \%$ give up work altogether $[4,14,15]$, with no difference between males and females [6].

\subsection{Support for working carers}

In Sweden, the need to support working carers is receiving attention from policy and carer organisa- tions $[13,16]$. Family care support may consist of several forms in four areas addressing carer needs: 1) Health and social care management, such as to learn and access information about caring issues of relevance to their own situation (e.g., about the care recipient's needs and available support); have practical assistance in caring (e.g., via information and training in care provision) and in planning and coordination of care/help/support; 2) Social, peer-to-peer, and emotional support, such as to talk about their situation and share their experiences with others (e.g., to cope with caregiving) via social support, counselling, and carer support groups; 3) Carer relief and respite care, and care recipient independence, such as to have access to relief and respite care (temporary supervision of the care recipient by a formal care provider to relieve family carers) and day care for the care recipient; and 4) Financial support [17-19]. Anecdotal reports from Swedish municipal family support units imply that existing services such as information, counselling, and carer support groups are underused by working carers $[15,16]$. Earlier empirical evidence validates such claims, with data indicating that Swedish working carers, especially non-cohabiting/working daughters of older care recipients, report low frequency of use and limited benefit of support [17]. Be that as it may, in these studies the perspectives of working spousal carers seem underrepresented, and results are based on a fairly narrow definition of support and venues for implementation.

Other forms of support may also be added to the list above, such as various information and communication technologies (ICTs). These are increasingly recognized as innovative means to increase accessibility of, and flexibility in, support [20]. ICT-mediated support, such as support available via the Internet, has been proposed as a means to provide Swedish working carers with flexible access to information, psychosocial support, and learning opportunities, which would otherwise be difficult to obtain due to limited time while working and providing care $[21,22]$. Such forms of ICT-mediated support and social, peer-topeer, and emotional support have been reported to reduce carer burden [23,24] and stress [25-27]. Telecare and assistive technologies for remote monitoring, alerts and distance communication, used both outside and at the workplace, may help the care situation and promote independence of the care recipient [19]. In various countries (e.g., the United States and the United Kingdom), these forms of support for working carers are reported to reduce burden, provide re- 
lief and peace of mind from being relieved from caregiving duties and from knowing that the care recipient is safe [ct. [24,26,28]]. However, such forms of support may also produce an unintended burden arising from the additional responsibility of responding to alerts and from the daily maintenance of the technology [23]. ICT-mediated support can also have a positive effect on secondary stressors arising from workcare conflict [cf. [10,11]], connected to reduced workcare interference, and increased work productivity and work participation [26,27]. However, to our knowledge studies on support for particularly Swedish working carers that focuses on ICT-mediated support are still sparse.

\subsection{The present study}

The main aim of this study was to describe the perceived value of different forms of support among Swedish working carers of older people, with a focus on ICT-mediated support.

The primary research questions were: (1) What forms of support are valued? (2) How are ICT-mediated forms of support valued relative to non-ICT forms of support? and (3) To what extent are valued forms of support received? The secondary research questions were: (1) What aspects of working life are affected by providing care? and (2) are caring characteristics and work-care conflict associated with the perceived value of forms of support?

\section{Methods}

\subsection{Design}

A cross-sectional questionnaire-based survey design was used as we wished to access a broad range of carers and measure their perceived value of support at a set point in time.

\subsection{Sampling frame and participants}

A convenience sampling strategy was used to recruit participants via two channels, the Swedish Dementia Association (Svenska Demensförbundet) and Carers Sweden (Anhörigas Riksförbund) as a way to access a sample of working carers from a large, estimated population of working carers. Inclusion criteria for participants were: being over 18 years of age; being self-employed or in paid employment/work; and presently caring for a person aged 65 years or older. A total of 129 participants were recruited. Due to the nature of the recruitment process (see Procedure, below), a response rate cannot be determined.

\subsection{Materials}

The questionnaire contained a selection of standard items for demographic information, items developed by the research team, and validated items and/or scales. The questionnaire consisted of four main sections: demographic details; the family care situation; work-care conflict; and valued and received forms of support.

\subsubsection{Demographic details}

Demographic information was obtained using a series of standard items to determine participant characteristics, such as age, gender, employment, and so forth.

\subsubsection{Family care situation}

Data on participants' family care situation was obtained using five items about the carer and the care recipient situation. Items addressed caring history and current caring circumstances. One item had dichotomous response options (e.g., "yes"/"no"), whereas four items had multiple choice response options from which participants could select those that applied to them.

\subsubsection{Work-care conflict}

The effect of caring on participants' work situation was measured by a single item. Participants were asked: How does providing care affect your working situation? The response format was multiple-choice, with participants selecting those response options that applied to them. The influence of work on the possibility to use support when providing care was measured via two items: Are work and care commitments too time-consuming to allow you to participate in carer support? If you have not used support for information, education, and carer network meetings during daytime, is this non-use due to work? Response options were: "very often," "often," "sometimes," "not at all," and "not sure." Work-care conflict was measured using the five-item work- care conflict Likert-type scale [10,11]. A forward and back translation procedure was used, as gold standard, to translate the five items from English into Swedish. Until agreement, first and third author translated items into Swedish and fourth and last author, both Swedish and native English speakers, translated back into English. Participants were asked to rate: 
worry for the care recipient; lower energy levels; stress over phone calls from, and about, the care recipient while at work; work absenteeism; and self-perceived quality of performed work. The response options for all items were $1=$ "totally disagree," 2 = "partly disagree," 3 = "partly agree," and 4 = "totally agree." The scale score was the mean of the scores for the five items (range 1-4), with a high score representing high work-care conflict. Cronbach's alpha for the scale in this study was 0.85 .

\subsubsection{Valued and received forms of support}

The perceived value of support was measured using 10 items about, or related to, ICT-mediated support, and 14 items about non-ICT support. Items about non-ICT support addressed common forms of support and were drawn from the employers for carers' survey [29], and from literature reviews conducted within the Swedish Family Care Competence Centre. Further items on ICT-mediated support were included following a literature review [19]. Value of support is conceptualized and measured as something that is perceived regardless of whether or not that support has been experienced. Participants were asked to rate how valuable the forms of support would be to them in their situation as a working carer. Response options for each item were: "it would be very"/“quite"/“"a little"/"not valuable to me" and "I don't know."

Receipt of support was assessed by listing 13 different forms of support for caring and asking participants to indicate which of the forms of support they had received outside of their workplace. An option to specify an 'other' form of support was also provided.

\subsection{Procedure}

An advertisement for the study was placed in a member bulletin of the Swedish Dementia Association in February 2016, and also sent in May 2016 via an email registry of delegates that had previously attended the annual National Carers' Day conference (Anhörigriksdagen) organized by Carers Sweden. The advert directed potential participants to a website containing an online questionnaire. For the Swedish Dementia Association potential participants were also offered a paper-based format, which none of the participants requested. The questionnaire was accessible from February to July 2016. One advert update was placed in the Swedish Dementia Association member bulletin and two email reminders were sent out to Carers Sweden's email registry.

\subsection{Data analysis}

SPSS v. 23.0 was used for all statistical analyses. Descriptive (univariate) statistics were used to describe the sample characteristics and study variables. Spearman's rho $\left(r_{s}\right)$ was calculated for associations between the perceived value of support and work-care conflict, while point biserial correlation $\left(r_{p b}\right)$ was calculated for associations between the perceived value of support and carer characteristics (being a spouse/non-spouse and dementia/non-dementia carer). Reliability analysis was performed to calculate Cronbach's alpha $(\alpha)$ as a measure of the internal consistency of the work conflict scale. Alpha was set at $p<0.05$ for each test, with no adjustment for multiple testing; note should therefore be taken of the potential for an inflated type I error rate, and consideration given to the effect size of significant associations.

The response options "very often," "often," and "sometimes," for the questions on the influence of work on using support were collapsed into one category. The response options for the perceived value of support were collapsed from four into two, with "very" and "quite" combined and "a little" and "not" combined. The 24 forms of support were categorized, via a triangulation process involving study authors (SA, LM, $\mathrm{EH}, \mathrm{KM}$ ) until consensus, into four support areas (as listed in the Introduction), and another category, i.e., support that didn't fit in to a clear category.

\subsection{Ethics}

This study was conducted in compliance with ethical principles of the Helsinki Declaration [30] and was approved by the Swedish regional ethics committee (dnr 2016/8-31)

\section{Results}

\subsection{Demographic characteristics}

Descriptive data on the sample is presented in Table 1 . The majority of the sample was female ( $n=$ 98; 95.1\%), married/cohabiting $(n=87 ; 84.5 \%)$, college or university-educated $(n=78 ; 75.7 \%)$, and aged $45-65$ ( $n=86 ; 83.5 \%)$. The majority of participants worked full-time ( $n=70 ; 64.8 \%$ ), with most employed in administrative work $(n=38 ; 40.9 \%)$.

\subsection{Family care situation}

The majority of participants had been caring for their care recipient for more than 4 years $(n=78$; 
Table 1

Participant demographic and care situation characteristics $(N=129)$

\begin{tabular}{|c|c|c|c|c|c|}
\hline & $N$ & $\%$ & & $N$ & $\%$ \\
\hline Gender & & & Weekly caring hours & & \\
\hline Female & 98 & 95.1 & $1-5$ hours & 63 & 48.8 \\
\hline Male & 5 & 4.9 & $6-10$ hours & 29 & 22.5 \\
\hline Age, years & & & 11-20 hours & 13 & 10.1 \\
\hline $30-44$ & 11 & 10.7 & 21-34 hours & 11 & 8.5 \\
\hline $45-65$ & 86 & 83.5 & $>34$ hours & 13 & 10.1 \\
\hline $66-77$ & 6 & 5.8 & Relationship to the care recipient & & \\
\hline Relationship & & & Adult child/children-in-law & 88 & 68.2 \\
\hline Married/cohabiting & 87 & 84.5 & Spouse/partner & 31 & 24.0 \\
\hline Unmarried & 14 & 13.6 & Other & 10 & 7.8 \\
\hline Partners living separately & 2 & 1.9 & Diagnosis of the care recipient & & \\
\hline Education & & & Dementia & 71 & 55 \\
\hline High school & 25 & 24.3 & Frailty & 13 & 10.1 \\
\hline College/university & 78 & 75.7 & Physical impairment/disability & 5 & 3.9 \\
\hline Employment & & & Other & 40 & 31 \\
\hline Full-time & 70 & 64.8 & Living and caregiving situation & & \\
\hline Part-time & 26 & 24.2 & Cohabiting with the care recipient & 26 & 20.2 \\
\hline Seeking employment & 1 & 0.9 & Caring for a person living alone in his/her own dwelling & 55 & 42.6 \\
\hline Self-employed & 11 & 10.1 & Caring for a person cohabiting with another person in & 19 & 14.7 \\
\hline \multicolumn{6}{|c|}{ his/her own dwelling } \\
\hline Administration & 38 & 40.9 & Caring for a person living in a caring home & 29 & 22.5 \\
\hline Operational work/production & 32 & 34.4 & & & \\
\hline Manager & 23 & 24.7 & & & \\
\hline \multicolumn{6}{|l|}{ Caring duration } \\
\hline$<6$ months & 3 & 2.3 & & & \\
\hline $6-11$ months & 6 & 4.7 & & & \\
\hline $1-3$ years & 42 & 32.6 & & & \\
\hline 4-6 years & 31 & 24.0 & & & \\
\hline$>7$ years & 47 & 36.4 & & & \\
\hline
\end{tabular}

$60.4 \%)$ and was caring for a parent/parent-in-law $(n=$ $88 ; 68.2 \%)$, in a large number of cases a care recipient with dementia $(n=71 ; 55 \%)$. Just over half of the sample ( $n=66 ; 51.2 \%$ ) provided 6 hours or more of care per week. The majority ( $n=100 ; 77.5 \%$ ) cared for someone living in her/his own dwelling, or for someone with whom they were cohabiting. Further data on the care situation is presented in Table 1.

\subsection{Work-care conflict}

Relatively few participants indicated that their caring role did not influence their work ( $n=17 ; 14.8 \%$ ). Data on how the remaining ( $n=98$ ) participants' caring commitments affected their working situation is presented in Table 2. The majority of participants indicated that their work was affected by psychological and physical strain arising from their caring role, i.e., by being worried about the older person while at work ( $n=72 ; 81.8 \%)$ and having less energy for work ( $n=70 ; 77.8 \%$ ). Fewer participants reported that their caring role affected logistical or practical aspects of their work, although in some cases these effects were reported by a substantial number (e.g., be- ing disturbed by telephone calls about, and from, the care recipient during work, ( $n=47 ; 53.4 \%)$; using vacation days ( $n=42 ; 42.9 \%)$ and adapting their work ( $n=32 ; 32.7 \%$ ) to be able to provide care). The mean score for participants' responses to the five items of the work-care conflict scale was $2.30(\mathrm{SD}=0.85)$, close to the mid-point of the scale (note: additional analysis found no significant difference in work-care conflict between carers of home-based care-recipients, and carers of care-recipients in residential care). Table 2 also shows that about a third of participants was unable to access support groups for information, education, and carer networking during their day due to work, while two-fifths did not have time to use carer support due to work and care commitments.

\subsection{Valued forms of support and support areas}

Table 3 shows, for each form of support, the proportion of participants who indicated the support was very/quite valuable, and the proportion who indicated the support was a little/not valuable. Nearly two-thirds ( $n=15,62.5 \%$ ) of the forms of support was valued by $50 \%$ or more of the sample. The most valued form 
Table 2

Participants responding affirmatively to questions on the influence of care on work, work-care influence, and accessing carer support $(N=129)$

\begin{tabular}{|c|c|c|}
\hline & $n$ & $\%$ \\
\hline \multicolumn{3}{|l|}{ Care influence on the work situation ${ }^{1}$} \\
\hline Vacation days used to be able to provide care & 42 & 42.9 \\
\hline Adapted work or changed jobs to be able to provide care & 32 & 32.7 \\
\hline Reduced working hours to be able to provide care & 18 & 18.4 \\
\hline Refrained from seeking or taking on other work due to caring & 17 & 17.3 \\
\hline Taken sick leave as a consequence of caring & 14 & 14.3 \\
\hline Taken on less qualified work/responsibility to be able to provide care & 8 & 8.2 \\
\hline I don't know & 5 & 5.1 \\
\hline Other & 7 & 7.1 \\
\hline \multicolumn{3}{|l|}{ Work-Care influence during the last two months ${ }^{2}$} \\
\hline Being worried about the older person while at work & 72 & 81.8 \\
\hline Having less energy for work & 70 & 77.8 \\
\hline Being disturbed by telephone calls about and from the cared for person during work & 47 & 53.4 \\
\hline Having lost to many workdays & 28 & 31.8 \\
\hline Less self-perceived quality of performed work & 27 & 31.0 \\
\hline \multicolumn{3}{|l|}{ Influence on carer using support ${ }^{3}$} \\
\hline Has not participated in carer support for him/herself because work and care commitments have been too time-consuming & 44 & 38.6 \\
\hline Has not used support for information, education, or carer network meetings during daytime due to work & 39 & 34.9 \\
\hline
\end{tabular}

${ }^{1}$ Based on dichotomised responses ("yes"/"no"). $n=98$ due to missing and non-applicable cases. ${ }^{2}$ Likert - type items of the work-care conflict scale. "Totally" and "partly agreed" are combined and presented as one response. Due to missing cases and non-applicable cases, $n=88-90$.

${ }^{3}$ Based on Likert type-item responses. "Very often," "often," and "sometimes" are combined and presented as one. Due to missing cases, $n=$ $114-112$.

of support was ICT-mediated (web access to information, $n=86 ; 76.8 \%$ ), but otherwise eight out of the ten ICT-mediated forms of support were valued by less than half the participants. By comparison, only one of the non-ICT forms of support was valued by under half the participants.

In terms of the most valued support areas, when considering ICT-mediated support Health and social care management was the most valued support area $(63.6 \%$ of participants, as an average of two forms of support within this area), followed by Social, peer-to-peer, and emotional support $(47.7 \%$ of participants, one form of support), then Carer relief and respite care, and care recipient independence $(38.1 \%$ of participants, averaged across five forms of support combined). For non-ICT support, Health and social care management was the most valued support area (63.6\% of participants, an average of four forms of support), followed by Social, peer-to-peer, and emotional support $(58.7 \%$ of participants, averaged across six forms of support), then Financial support (55.2\%, one form of support) and finally Carer relief and respite care, and care recipient independence $(52.7 \%$, an average of three forms of support). Thus, the ranking of support area by value was comparable between the two delivery modes, but the level of value was generally higher when the mode of delivery was non-ICT. It should also be acknowledged that the level of value for forms of support could range substantially within a given support area. Thus, within the Carer relief and respite care and care re- cipient independence support area (non-ICT) whereas nearly two-thirds of the sample valued relief from caring through the help of family and friends $(n=67$; $63.9 \%)$, only just over a third of the sample $(n=37$; $35.3 \%$ ) valued help to rest and have time for themselves e.g., through respite care. However, the majority of participants ( $n=66 ; 58.9 \%$ ) valued having information about where and how to get time for self and rest.

\subsection{Received forms of support}

Of the fourteen possible forms of support specified (including 'other'), the median number received by participants was $2.0(n=110$; IQR 1.0-3.0). For those forms of support for which data was gathered on both value and receipt $(n=11)$, we examined the proportion of participants who received a valued form of support. Thus, Fig. 1 shows, for those participants who responded that a form of support was valued, the proportion that was and the proportion that was not in receipt of that support. As would be anticipated given the low median value for the number of forms of support received, in general the proportion of participants in receipt of valued support was low. Averaged across the 11 forms of support, the proportion of participants in receipt of valued support was $21.7 \%$.

The proportion of participants in receipt of ICTmediated support averaged at $16.9 \%$ across three forms of support. However, this average hides very low lev- 
Table 3

Perceived value of different forms of support $(N=129)$

\begin{tabular}{|c|c|c|c|c|}
\hline \multirow[t]{2}{*}{ Forms of support ${ }^{1}$} & \multicolumn{2}{|r|}{$\begin{array}{l}\text { "Very"/ } \\
\text { "quite } \\
\text { valuable" }\end{array}$} & \multirow{2}{*}{$\begin{array}{c}\text { "A little"/ } \\
\text { "not } \\
\text { valuable" } \\
\%\end{array}$} & \multirow[b]{2}{*}{ Support area } \\
\hline & $n$ & $\%$ & & \\
\hline \multicolumn{5}{|l|}{ ICT-mediated support } \\
\hline To have access to information via the web & 112 & 76.8 & 10.7 & Health and social care management \\
\hline $\begin{array}{l}\text { To be able to participate in meetings for care planning or } \\
\text { doctors' appointments at a distance via computers, tablets, } \\
\text { smartphones, and TV screens }\end{array}$ & 107 & 50.4 & 40.2 & Health and social care management \\
\hline $\begin{array}{l}\text { To be introduced to available technical aids, such as alarms, } \\
\text { sensors, and equipment for communication }\end{array}$ & 105 & 49.5 & 33.4 & $\begin{array}{l}\text { Relief and respite care, or care recipient } \\
\text { independence }\end{array}$ \\
\hline $\begin{array}{l}\text { To be able to meet other cares via forums on the web to share } \\
\text { experiences }\end{array}$ & 109 & 47.7 & 41.2 & Social, peer-to-peer, and emotional support \\
\hline $\begin{array}{l}\text { To have the possibility to use technologies during work hours } \\
\text { (e.g., alarms, cameras, video, GPS) }\end{array}$ & 105 & 42.8 & 40.9 & Other \\
\hline $\begin{array}{l}\text { To be able to communicate with the care recipient from a } \\
\text { distance via computers, tablets, smartphones, and TV screens }\end{array}$ & 107 & 40.2 & 47.6 & $\begin{array}{l}\text { Relief and respite care, or care recipient } \\
\text { independence }\end{array}$ \\
\hline $\begin{array}{l}\text { To be alerted in case of falls, or of use of windows and doors, } \\
\text { via sensors and cameras in the home of the care recipient }\end{array}$ & 107 & 34.6 & 46.7 & $\begin{array}{l}\text { Relief and respite care, or care recipient } \\
\text { independence }\end{array}$ \\
\hline $\begin{array}{l}\text { To be able to receive information about the care recipient, or } \\
\text { to be able locate where the care recipient is outside the home, } \\
\text { e.g. via GPS }\end{array}$ & 107 & 34.6 & 50.5 & $\begin{array}{l}\text { Relief and respite care, or care recipient } \\
\text { independence }\end{array}$ \\
\hline $\begin{array}{l}\text { To receive information, via different technology solutions, } \\
\text { about whether the care recipient has used the stove, refriger- } \\
\text { ator, pill dispenser, toilet door, or bed }\end{array}$ & 108 & 31.8 & 54.2 & $\begin{array}{l}\text { Relief and respite care, or care recipient } \\
\text { independence }\end{array}$ \\
\hline $\begin{array}{l}\text { To be able to remain anonymous when meeting other carers } \\
\text { Non-ICT-mediated support }\end{array}$ & 109 & 25.7 & 56.9 & Other \\
\hline $\begin{array}{l}\text { To have access to information about where to get help for the } \\
\text { care recipient }\end{array}$ & 112 & 72.3 & 14.3 & Health and social care management \\
\hline $\begin{array}{l}\text { Emotional support- to be able to talk to someone about one's } \\
\text { situation' }\end{array}$ & 109 & 66.9 & 24.8 & Social, peer-to-peer, and emotional support \\
\hline $\begin{array}{l}\text { To receive more assistance with planning and coordination } \\
\text { of care/help/support }\end{array}$ & 105 & 64.8 & 20.0 & Health and social care management \\
\hline To get information on how to get support as a carer & 112 & 64.3 & 20.5 & Social, peer-to-peer, and emotional support \\
\hline $\begin{array}{l}\text { To get more relief in caring with help from other family and } \\
\text { friends }\end{array}$ & 105 & 63.9 & 23.8 & $\begin{array}{l}\text { Relief and respite care, or care recipient } \\
\text { independence }\end{array}$ \\
\hline $\begin{array}{l}\text { To get support from the family care support unit in the mu- } \\
\text { nicipality }\end{array}$ & 109 & 60.2 & 27.5 & Social, peer-to-peer, and emotional support \\
\hline $\begin{array}{l}\text { To have help to have assistive aids introduced and adaptions } \\
\text { made at the home of the care recipient }\end{array}$ & 105 & 60.0 & 27.6 & Health and social care management \\
\hline $\begin{array}{l}\text { To access information about where and how to get time for } \\
\text { self and rest, respite }\end{array}$ & 112 & 58.9 & 21.4 & $\begin{array}{l}\text { Relief and respite care, or care recipient } \\
\text { independence }\end{array}$ \\
\hline $\begin{array}{l}\text { To receive more help performing domestic tasks in caring, } \\
\text { e.g., cleaning, gardening, shopping }\end{array}$ & 105 & 57.2 & 29.5 & Health and social care management \\
\hline $\begin{array}{l}\text { To access information about, or to get into contact with, the } \\
\text { municipal family care support }\end{array}$ & 112 & 57.1 & 25.0 & Social, peer-to-peer, and emotional support \\
\hline To receive financial reimbursement for caring & 105 & 55.2 & 34.2 & Financial support \\
\hline $\begin{array}{l}\text { To be able to meet other carers onsite (face-to-face) in groups } \\
\text { to share experiences }\end{array}$ & 109 & 53.2 & 39.4 & Social, peer-to-peer, and emotional support \\
\hline To enjoy social support, e.g., carer support, carer groups & 105 & 50.4 & 36.7 & Social, peer-to-peer, and emotional support \\
\hline $\begin{array}{l}\text { To be able to rest and have time for self ,e.g., through respite } \\
\text { care }\end{array}$ & 105 & 35.3 & 44.7 & $\begin{array}{l}\text { Relief and respite care, or care re indepen- } \\
\text { dence }\end{array}$ \\
\hline
\end{tabular}

${ }^{1}$ Due to missing cases, $\mathrm{n}$ varies across items; $\mathrm{n}$ per item is given where appropriate. "Don't know" responses are included in the calculation of percentages, but are not presented in the Table. GPS = global positioning system; ICT = information and communication technology.

els of receipt for two forms of web-based support, support for becoming informed and educated in caregiving $(n=6 ; 7.0 \%)$ and support for meeting peer carers $(n=4 ; 7.2 \%)$. By comparison, the receipt of technologies in the home of the care recipient (e.g., alarms and sensors) was considerably higher $(n=19 ; 36.5 \%)$.

The proportion of participants in receipt of non-ICT support averaged at $23.4 \%$ across eight forms of support. The lowest level of receipt was for support enabling rest or time for self, respite care, which was re- 


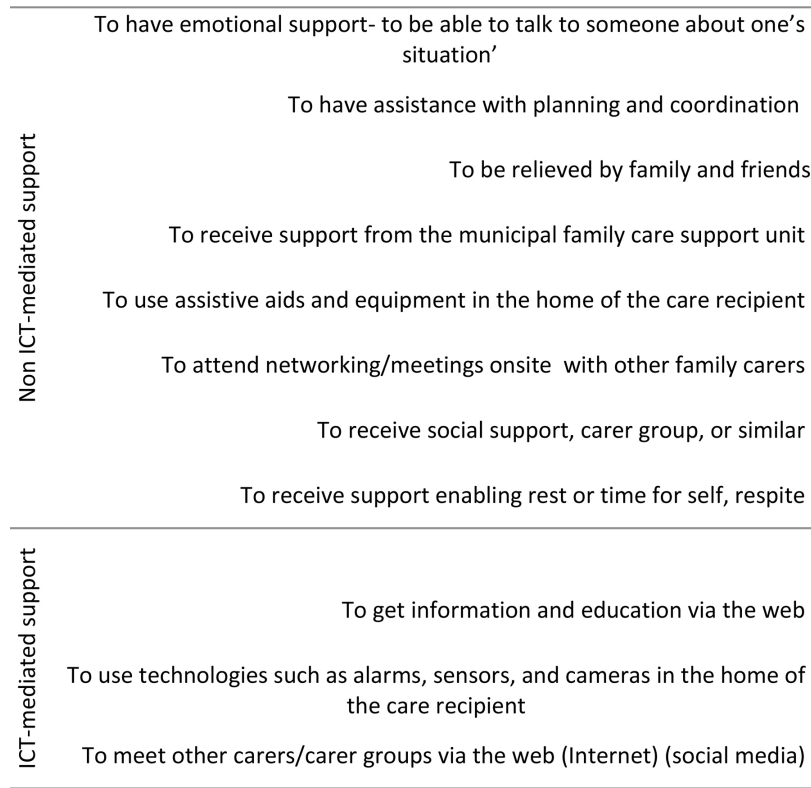

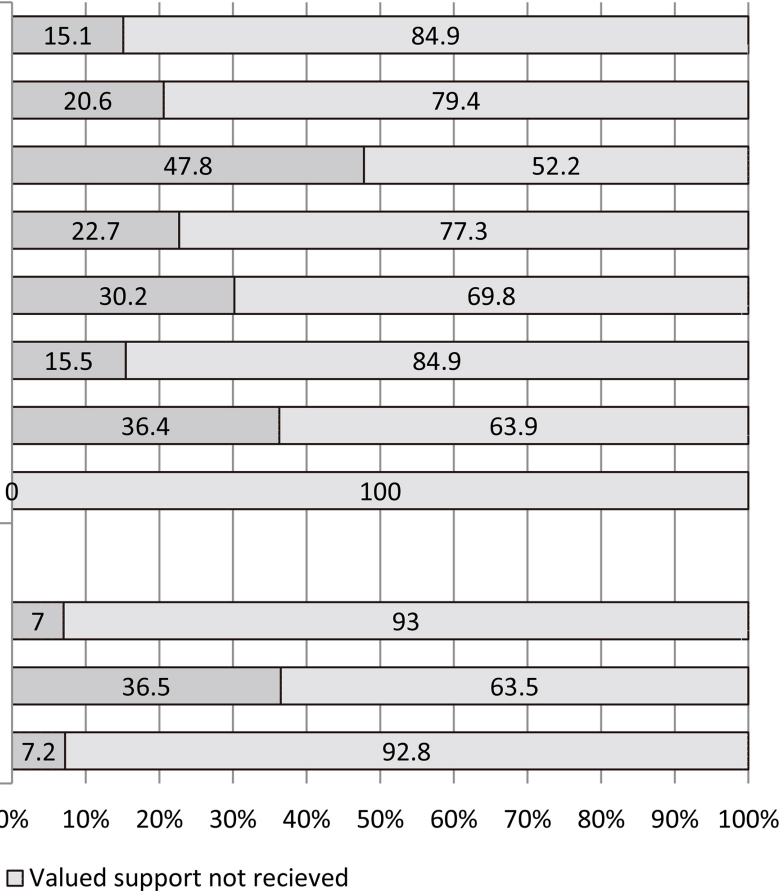

$\square$ Valued support received

$\square$ Valued support not recieved

Fig. 1. Proportion of participants receiving valued forms of support.

ceived by none of the 33 participants who valued that support, while the highest level of receipt was for relief received from family and friends $(n=32,47.8 \%)$.

\subsection{Associations between value of support, caregiving characteristics, and work-care conflict}

The bivariate associations between caregiving characteristics, work-care conflict, and value of support are presented in Table 4, separately for ICT-mediated and non-ICT based support.

\subsubsection{ICT-mediated support}

Being a spouse vs. non-spouse carer was not significantly associated with the value of support for any of the ICT-mediated forms of support. Caring for a person with dementia was associated with a higher value for being introduced to available technical assistive devices, such as alarms, sensors, and equipment for communication $\left(r_{p b}(87)=0.261 ; p<0.05\right)$, and use of such technologies in the home of the care recipient for emergency alerts (e.g., in case of falls, use of windows and doors) $\left(r_{p b}(87)=0.230 ; p<0.05\right)$.

Six out of the ten associations between the workcare conflict scale and the value of ICT-mediated forms of support were significant, all indicating that higher levels of work-care conflict were associated with higher levels of value. The strongest associations were between high work-care conflict and high value for being introduced to available technical assistive devices (i.e., alarms, sensors, and equipment for communication) $\left(r_{p b}(84)=0.458 ; p<0.01\right)$, the receipt of information on, and equipment for, locating the care recipient outside the home $\left(r_{p b}(87)=0.346 ; p<0.01\right)$, and using technologies (e.g., alarms and sensors) during working hours $\left(r_{p b}(85)=.325 ; p<0.01\right)$.

\subsubsection{Non-ICT support}

Caring for someone with/without dementia was associated with the value of only one form of support, indicating that caring for someone with dementia was associated with a higher value for more assistance with planning and coordination of care/help/support $\left(r_{p b}(89)=0.227 ; p<0.05\right)$.

Four out of the fourteen associations between being a spouse vs. non-spouse carer and the value of non-ICT forms of support were significant, all indicating that being a spouse carer was associated with higher levels of value. The strongest associations were between being a spouse carer and higher values for being able to meet other carers onsite in groups to share experiences $\left(r_{p b}(101)=0.249 ; p<0.05\right)$, and with being able to 
Table 4

Perceived value of forms of support: associations with care characteristics and work-care conflict $(N=129)$

\begin{tabular}{|c|c|c|c|c|c|c|}
\hline \multirow[t]{2}{*}{ Forms of support } & \multicolumn{2}{|c|}{$\begin{array}{l}\text { Dementia/non- } \\
\text { dementia carer }\end{array}$} & \multicolumn{2}{|c|}{$\begin{array}{l}\text { Spouse/non- } \\
\text { spouse }\end{array}$} & \multicolumn{2}{|c|}{$\begin{array}{l}\text { Work-care } \\
\text { conflict }\end{array}$} \\
\hline & $n$ & $r_{p b}$ & $n$ & $r_{p b}$ & $n$ & $r_{s}$ \\
\hline \multicolumn{7}{|l|}{ ICT-mediated support } \\
\hline To have access to information via the web & 98 & 0.052 & 98 & -0.055 & 94 & $0.298 * *$ \\
\hline $\begin{array}{l}\text { To be able to participate in meetings for care planning or doctors' appointments } \\
\text { at a distance via computers, tablets, smartphones, and TV screens }\end{array}$ & 97 & 0.031 & 97 & -0.165 & 93 & 0.066 \\
\hline $\begin{array}{l}\text { To be introduced to available technical aids, such as alarms, sensors, and equip- } \\
\text { ment for communication }\end{array}$ & 87 & $0.261 *$ & 87 & 0.029 & 84 & $0.458 * *$ \\
\hline To be able to meet other carers via forums on the web to share experiences & 97 & 0.196 & 97 & 0.056 & 93 & 0.187 \\
\hline $\begin{array}{l}\text { To have the possibility to use technologies during work hours (e.g., alarms, cam- } \\
\text { eras, video, GPS) }\end{array}$ & 88 & 0.148 & 88 & 0.045 & 85 & $0.325 * *$ \\
\hline $\begin{array}{l}\text { To be able to communicate with the care recipient from a distance via computers, } \\
\text { tablets, smart phones and TV-screens }\end{array}$ & 94 & 0.011 & 94 & -0.112 & 91 & $0.240 *$ \\
\hline $\begin{array}{l}\text { To be alerted in case of falls, or of use of windows and doors, via sensors and } \\
\text { cameras in the home of the care recipient }\end{array}$ & 87 & $0.230 *$ & 87 & -0.030 & 84 & 0.167 \\
\hline $\begin{array}{l}\text { To be able to receive information about the care recipient, or to be able locate } \\
\text { where the care recipient is outside the home, e.g. via GPS }\end{array}$ & 91 & 0.201 & 91 & 0.058 & 87 & $0.346 * *$ \\
\hline $\begin{array}{l}\text { To receive information, via different technology solutions, about whether the } \\
\text { care recipient has used the stove, refrigerator, pill dispenser, toilet door, or bed }\end{array}$ & 92 & 0.140 & 92 & 0.007 & 87 & $0.267 *$ \\
\hline To be able to remain anonymous when meeting other carers & 90 & 0.006 & 90 & 0.137 & 85 & 0.094 \\
\hline \multicolumn{7}{|l|}{ Non-ICT-mediated support } \\
\hline To have access to information about where to get help for the care recipient & 97 & 0.109 & 97 & 0.071 & 93 & $0.330 * *$ \\
\hline To have emotional support- to be able to talk to someone about one's situation' & 100 & 0.009 & 100 & $0.216 *$ & 95 & $0.438 * *$ \\
\hline To get information on how to get support as a carer & 95 & -0.025 & 95 & 0.078 & 90 & $0.219 *$ \\
\hline $\begin{array}{l}\text { To have help to have assistive devices introduced and adaptions made at the home } \\
\text { of the care recipient }\end{array}$ & 92 & 0.089 & 92 & 0.004 & 90 & $0.274 * *$ \\
\hline To receive more assistance with planning and coordination of care/help/support & 89 & $0.227 *$ & 89 & 0.172 & 85 & $0.415 * *$ \\
\hline To get more relief in caring with help from other family and friends & 92 & 0.137 & 92 & 0.023 & 89 & $0.356 * *$ \\
\hline To access information about where and how to get time for self and rest, respite & 90 & -0.010 & 90 & 0.183 & 86 & $0.299 * *$ \\
\hline To get support from the family care support unit in the municipality & 96 & 0.034 & 96 & 0.171 & 91 & $0.222 *$ \\
\hline $\begin{array}{l}\text { To access information about, or to get into contact with, the municipal family } \\
\text { care support }\end{array}$ & 92 & 0.071 & 92 & -0.020 & 87 & 0.149 \\
\hline $\begin{array}{l}\text { To receive more help performing domestic tasks in caring, e.g., cleaning, garden- } \\
\text { ing, shopping }\end{array}$ & 91 & -0.009 & 91 & -0.006 & 89 & $0.255 *$ \\
\hline $\begin{array}{l}\text { To be able to meet other carers onsite (face-to-face) in groups to share experi- } \\
\text { ences }\end{array}$ & 101 & 0.097 & 101 & $0.249 *$ & 97 & $0.286 * *$ \\
\hline To receive financial reimbursement for caring & 94 & -0.116 & 94 & 0.135 & 89 & $0.356 * *$ \\
\hline To enjoy social support, e.g., carer support, carer groups & 95 & -0.142 & 95 & $0.237 *$ & 91 & $0.322 * *$ \\
\hline To be able to rest and have time for self, e.g., through respite care & 84 & 0.171 & 84 & $0.262 *$ & 80 & $0.355 * *$ \\
\hline
\end{tabular}

Note: $n$ : s are based on pairwise deletion of missing cases. $r_{p b}=$ bivariate point-biserial correlation. $r_{s}=$ bivariate correlation using Spearman's rho. ${ }^{*} p<0.05 ;{ }^{* *} p<0.01$.

rest and have time for self, e.g., through respite care $\left(r_{p b}(84)=0.262 ; p<0.05\right)$.

Thirteen out of the fourteen associations between scores on the work-care conflict scale and the value of non-ICT forms of support were significant, all indicating that higher levels of work-care conflict were associated with higher levels of value. The strongest associations were between high levels of work-care conflict and higher value for being able to talk with someone (emotional support) $\left(r_{p b}(95)=0.438 ; p<0.01\right)$, more assistance with planning and coordination of care $\left(r_{p b}(85)=0.415 ; p<0.01\right)$, getting more relief from family and friends $\left(r_{p b}(89)=0.356, p<0.01\right)$, being able to rest and have time for self, e.g., through respite care $\left(r_{p b}(80)=0.355, p<0.01\right)$, and receiving finan- cial reimbursement for caring $\left(r_{p b}(89)=0.356, p<\right.$ $0.01)$.

\section{Discussion}

This study makes a contribution by providing new knowledge on support for Swedish working carers that focuses on ICT-mediated support, an area where our current understanding is relatively poor. Our research questions asked which ICT and non-ICT forms of support are valued by working carers of older people, and to what extent valued forms of support are received. We also asked whether the provision of care affected work commitments and whether, and how, work-care 
conflict was associated with the perceived value of forms of support among carers.

Our main findings indicate that most forms of support were valued by the majority of participants, with, overall, non-ICT forms of support being more highly valued. However, among those participants who valued a form of support, only a minority received that support, and this was true for both ICT and non-ICT forms of support. Most participants indicated that their work was affected by their care situation, with most reporting that their work was affected due to the psychological and physical strain arising from their caring role. Fewer participants indicated that their caring role affected the logistical or practical aspects of their work, although the proportion affected was still substantial. The importance of work-care conflict was underlined by the finding that participants who scored higher on the work-care conflict scale perceived higher value in nearly all forms of support. By comparison, such key characteristics of the care situation as being a spouse or non-spouse carer or caring for someone with or without dementia had fewer associations with the perceived value of support.

\subsection{Perceived value of ICT-mediated and non-ICT forms of support}

Forms of support in the area of health and social care management were the most valued by participants, regardless of whether they were ICT-mediated or not. This finding is given credence by research acknowledging that carers are particularly stressed when lacking information, and, with regard to working carers, when being obliged to organise, plan, and coordinate health and social care $[6,31]$. The relatively lower level of perceived value for social, peer-to-peer, and emotional forms of support found in our study are reflected in research reporting low frequency of use and limited benefit of municipally organised support groups among Swedish working carers [13-17]. Further, the relatively lower perceived value of support for relief and respite, e.g., through respite care in our study, has been reflected in research on Swedish working daughters low service use when caring of older care recipients refusing such services when allowed to decide her/his own care arrangements [17].

When comparing the perceived value of ICTmediated forms of support to non-ICT forms of support, we would argue that our results suggest that ICTmediated support is complementary to non-ICT support. Firstly, having information (e.g., about support for the carer and the care recipient) and getting assistance with planning and coordination for health and social care management were highly valued. Using the web to access such information stands out in our results as the most valued support. Further, the ability to participate in care planning or doctor's appointments from a distance via ICT may suggest an alternative means for working carers to stay informed, and may be valued when planning health and social care for their care recipients.

Secondly, a comparison of different modes for social and peer-to-peer support shows that web-based support for carers, allowing them to meet their peers, was only slightly less valued than an onsite, physical, meeting. This difference should be considered in the context of other findings of this study, i.e. the one-third of carers who indicated that they were unable to access support groups during the day due to work, the $40 \%$ who had no time to use carer support due to their work and care commitments, and the $25 \%$ that indicated a preference for anonymity when meeting other carers. ICTmediated forms of support would clearly have application for such carers, as also described by Andersson et al. [21]. A preference for physical meetings with other carers rather than ICT-mediated meetings may be related to experiencing fewer digital skills or the view that communication is too impersonal when not involving synchronous interaction or physical contact [21].

Thirdly, between one-third and two-fifths of participants valued information on safety and prevention via remote monitoring technologies. Such technologies may assist working carers in providing everyday care while maintaining their employment (e.g., alarms, sensors as a form of in-house respite care), as shown in Mahoney et al. [26] and Jarrold and Yeandle [28], and offer a viable alternative to traditional institutional respite care or day care at a time when the withdrawal of the welfare state and the increase in numbers of older people is putting pressure on such services in many countries, including Sweden [15]. Nevertheless, we found a higher perceived value for being introduced to telecare and assistive technologies than for actually using these forms of support for safety and preventive monitoring. This discrepancy may be due to participants seeing such technologies as more for supporting the care-recipient's independence and safety than being a support for themselves personally, i.e., as carers [19]. Alternatively, the discrepancy may indicate a general need for having such support available when required, as opposed to using such support when available, which is suggested as a key characteristic of sup- 
port need among European family carers [17]. Finally, nearly one-quarter of our participants cared for someone living in a residential care facility, which may have reduced the perceived value of all forms of respite care in our sample.

\subsection{Receipt of valued support}

The median number of different forms of support received by participants in our sample was two, which, when combined with the general low level of receipt of valued forms of support, suggests a poor level of received support for working carers. Though it cannot be stated for certain that something that has a high perceived value is in fact needed, still there is an argument to be made that our results suggest a high degree of unmet need for support in our participants. The forms of support that were considered in our study reflect those domains of support for which high levels of need have been found among carers in other research, namely, the need to be able to: (1) learn and access information about caring issues of relevance to their own situation; (2) talk about their situation and share their experiences with others; (3) have practical assistance in caring; and (4) have access to relief and respite care [32]. The low level of receipt of valued forms of support may indicate an underdeveloped municipal family support system, which fails to acknowledge the difficult situation of working carers and/or fails to provide information on the availability of support and how to access it $[13,16,33]$.

\subsection{The influence of caring on working life}

Our results confirm those from other studies, namely that caring influences working life [6,34]. Our results show that the great majority of participants had been affected in their work situation by their caring role. Psychological and physical strain arising from their caring role (i.e., worry about the older person while at work and having less energy for work) was the most commonly reported effect; however, a substantial number of participants were also affected logistically or practically (e.g., adapting their work for caring, losing too many workdays, or finding new work).

Our analyses also demonstrated a strong link between higher levels of work-care conflict and a higher perceived value of support, for both ICT-mediated and non-ICT forms of support. The most common contributions to work-care conflict in this study, as measured via the items of the work-care conflict scale, were worry about the care recipient, having less energy for work, and being disturbed at work by phone calls about, and from, the care recipient. Interestingly, the strongest associations between work-care conflict and value of support were found for those forms of support that may address such contributing factors: namely, being introduced to available technologies such as alarms, and using such technologies for locating the care recipient (not for emergency alerts), especially during work hours. Our findings reflect those of other studies, where working carers experience peace of mind and emotional and physical respite from using such technologies [24,26,28,35]. Also, using the described technologies during work hours in worksite programs may allow working carers to better balance care and work, thus reducing the negative impacts of caring [21], although a different research design than that of the present study would be required to test this claim. While the associations between work-care conflict and perceived value of support cannot be viewed as causal due to the cross-sectional nature of our study, it is logically easier to argue that the direction of influence is that conflict between care and work increases the perceived value of support rather than that an increased value for support might cause an increase in work-care conflict.

It is acknowledged that caring for someone with dementia, and for a spouse, can often strongly influence carers' support needs [36]. It is rather surprising, therefore, that these characteristics of the caring situation had relatively few associations with the perceived value of different forms of support. One reason for this may be that the categories of dementia care vs. non-dementia care, and spouse vs. non-spouse, while defining characteristics of the caring role, are fairly unsophisticated descriptions and statistically insensitive measures of what is a highly complex care situation.

\subsection{Study strengths and weaknesses}

The study's main weakness relates to its convenience sample, which was obtained through two recruitment channels for which no response rate can be accurately determined. It is likely that our sample is therefore biased in unquantifiable ways, and may not be a good representation of our study population, which in itself offers only a limited representation of our target population. Our sample is representative in age distribution, marital status, weekly caring hours, relationship to the care recipient, and living and caregiving situation compared with Swedish national based 
surveys $[4,6]$. We do however acknowledge that our convenience sample has a majority of females. While most carers are female, the combination of a relatively small sample size with a large majority of females limited the extent to which we could carry out analyses by gender. Women are known to experience more mental and physical strain than men and experience more difficulties in finding time for leisure activities and reduced ability to focus on their job [6]. This may explain why a higher proportion of our sample, $18.3 \%$, had reduced their working hours compared to $10 \%$ reported in a survey conducted by the Swedish National Board of Health and Welfare [4].

We acknowledge that not knowing if participants have experienced or were aware of the existence of certain forms of support limits what conclusions can be drawn. Nevertheless, due to the questionnaire items identifying forms of ICT and non-ICT support that are relatively generic, we believe that a lack of awareness of such forms of support is likely to be low and bias in the analysis minimal.

We acknowledge that the web-based survey format required that our participants had some familiarity with accessing and using the internet and this may have biased our sample in favour of those carers with such experience. However, it should be noted that our other recruitment channel offered a paper-based survey format making it possible for carers with less experience of the internet to participate.

We also acknowledge $11.6-18.6 \%$ missing data in our questions on perceived value of support, received support, and work-care influence, which may have introduced bias into our analyses. Missing value analysis revealed patterns of not completing the whole questionnaire, i.e., giving up halfway through ( $n=$ 26), which may have to do with fatigue at finding the questionnaire too extensive, or having technical issues when completing the web-based questionnaire. However, an MCAR test [37] was non-significant, so the null hypothesis that our data are missing at random cannot be rejected. In our analyses, multiple bivariate tests were carried out, inflating the chance of type I error. However, we chose not to correct for this due to our relatively small sample for specific analyses also increasing the potential for type II error. Taking all the above information together, generalization of our findings to the wider population of working carers of older people must therefore be considered with due caution.

It might also be considered to what extent findings from a study concerning the perceived value of ICT-mediated and non-ICT forms of support among
Swedish working carers might have implications for understanding the situation of working carers in other countries. After all, there are substantial differences between countries relating to welfare systems, working and caring cultures, and ICT use. Nevertheless, we would argue that our findings should be of interest to academic, policy, and practitioner communities internationally, as working carers in many different countries experience the dual pressure to work longer and care more. Where there is a lack of services and support for working carers, the price for many is the loss of paid work, impaired health, and an uncertain financial future, as a study comparing the United Kingdom and Sweden has shown [33]. Understanding how workcare conflict relates to the value of different forms of support among working carers, particularly ICTmediated support, is critical from an international policy perspective given the reduction of welfare provision in many countries and the need to retain people of working age in the labour market [15].

\subsection{Conclusions and implications for policy and practice}

Our study found high levels of work-care conflict among working carers, with conflict associated with higher levels of perceived value for support, while receipt of valued forms of support was low. Taken together our findings suggest a worrying level of unmet support needs in working carers which is inflated by the work-care conflict they experience. Our findings are perhaps indicative of underdeveloped carer support in municipalities. These findings are relevant for health and social care professionals, municipalities and formal care organisations, and for employers wanting to develop strategies to meet the support needs of working carers of older people. While on one level we found non-ICT forms of support to be more highly valued by working carers than ICT-mediated forms, reflecting on different elements of our results suggests that ICT-mediated and non-ICT forms of support are highly complementary. We suggest that future research should explore the effects of ICT on relief and respite care, and the use of ICT at the worksite and in the planning and coordination of care.

\section{Acknowledgments}

The study was accomplished while SA was affiliated with the The Swedish National Graduate School for 
Competitive Science on Ageing and Health (SWEAH), which is funded by the Swedish Research Council.

This work formed part of a doctoral studentship that was financed by The Swedish Family Care Competence Centre as part of evaluation and practice development work commissioned by the earlier Swedish Institute for Assistive Technology to explore ICTs for working caregivers of older people.

\section{Conflict of interest}

None to report.

\section{References}

[1] Hoyer S, Reich N. Leave and financial support for family caregivers in EU member states. Observatory for Sociopolitical Developments in Europe, 2016. http//www.sociopoliticalobservatory.eu/uploads/tx_aebgppublications/2017_Report_ Support_family_caregivers_EN.pdf

[2] Rodrigues R, Huber M, Lamura, G. (eds.). Facts and Figures on Healthy Ageing and Long-term Care. European Centre for Social Welfare Policy and Research: Vienna, 2012.

[3] Eurocarers. Information and Communication Technology (ICT) for carers. 2016. https//eurocarers.org/publications/ information-and-communication-technology-ict-for-carers/.

[4] NBHWS. Anhöriga som ger omsorg till närstående (Family carers who gives care and support to family members). (In Swedish). Stockholm: National Board of Health and Welfare Sweden (Socialstyrelsen), 2012.

[5] Szebehely M, Ulmanen P, Sand A-B. Att ge omsorg mitt livet: hur påverkar det arbete och försörjning? Family care in mid-life: how it effects working life?. (In Swedish). Working Paper/Department of Social Work, 2014; 1.

[6] Ulmanen P. Kvinnors och mäns hjälp till sina gamla föräldrar: Innehåll, omfattning och konsekvenser (Women and mens' care provision of their older parents: Content, extent and consequenses). (In Swedish). Socialvetenskaplig Tidskrift. 2015; 22(2): 111-132.

[7] Nolan M, Grant G, Keady J. Understanding family care. Buckingham: Open University Press, 1996.

[8] Mckee KJ, Philp I, Lamura G, Prouskas C, Öberg B, Krevers B, Spazzafumo L, Bien B, Parker C, Nolan MR, Szczerbinska K. The COPE index - a first stage assessment of negative impact, positive value and quality of support of caregiving in informal carers of older people. Aging and Mental Health. 2003; $7:$ 39-52

[9] Balducci C, Mnich E, McKee KJ, et al. Negative impact and positive value in caregiving: validation of the COPE index in a six-country sample of carers. The Gerontologist. 2008; 48 : 276-286.

[10] Aneshensel CS, Pearlin LI, Mullan JT, Zarit SH, Whitlatch CJ. Profiles in caregiving: The unexpected career. San Diego, CA, US: Academic Press, 1995.

[11] Pearlin LI, Mullan JT, Semple SJ, Skaff MM. Caregiving and the stress process: an overview of concepts and their measures. The Gerontologist. 1990; 30(5): 583-594.
[12] Bauer JM, Sousa-Poza A. Impacts of Informal Caregiving on Caregiver Employment, Health, and Family. Journal of Population Ageing. 2015; 8: 113-145. doi: 10.1007/s12062-0159116-0.

[13] Sand AB. Anhöriga som kombinerar förvärvsarbete med anhörigomsorg, uppdaterad version (Family carers combining working life with care and support for a family member, updated version) (In Swedish) (Kunskapsöversikt 2016: 3): Nationellt kompetenscentrum Anhöriga (Swedish Family Care Competence Center), 2016.

[14] Principi A, Lamura G, Sirolla C, Mestheneos L, Bień B, Brown J, Krevers B, Melchiorre MG. Döhner H. Work restrictions experienced by midlife family care-givers of older people: evidence from six European countries. Ageing \& Society. 2014; 34(2): 209-231.

[15] Spasova S, Baeten R, Coster S, Ghailani D, Peña-Casas R. Vanhercke B. Challenges in long-term care in Europe. A study of national policies. European Social Policy Network (ESPN), Brussels: European Commission, 2018.

[16] Sand AB. Anhöriga som kombinerar förvärvsarbete med anhörigomsorg (Family carers combining working life with care and support for a family member) (In Swedish) (Kunskapsöversikt 2010: 3): Nationellt kompetenscentrum Anhöriga (Swedish Family Care Competence Center), 2010.

[17] Lamura G, Mnich E, Nolan M, Wojszel B, Krevers B, Mestheneos L, Döhner H. Family carers' experiences using support services in Europe: empirical evidence from the EUROFAMCARE study. The Gerontologist. 2008; 48: 752-771.

[18] Magnusson L, Hanson E, Larsson-Skoglund A, Ilett R, Sennemark E, Barbabella F, Gough R. Kvalitet i äldreomsorg ur ett anhörigperspektiv. (Quality of care for older people from a carer perspective, report commissioned as part of the examination of a national quality plan for carer of older people) ( $\mathrm{S}$ 2015:0) (In Swedish), Elanders Sweden Ltd, 2016.

[19] Andersson S, Erlingsson C, Magnusson L. Hanson E. Information and communication technology-mediated support for working carers of older family members: an integrative literature review. International Journal of Care and Caring. 2017; 1(2): 247-73. Doi: 10.1332/239788217X14957228181753

[20] Carretero S, Stewart J, Centeno C. Information and communication technologies for informal caregivers and paid assistants: benefits from micro-, meso-, and macro-levels. Eur Journal of Ageing. 2015; 12: 163-173.

[21] Andersson S, Erlingsson C, Magnusson L, Hanson E. The experiences of working carers of older people regarding access to a web-based family care support network offered by a municipality. Scandinavian Journal of Caring Sciences. 2016. doi: $10.1111 / \mathrm{scs} .12361$.

[22] Bergström Aileen L, Hanson E. An integrative review of information and communication technology-based support interventions for carers of home dwelling older people. Technology and Disability. 2017; 29(1-2): 1-14

[23] Chiu T, Marziali E, Colantonio A, Carswell A, Gruneir M, Tang M, Eysenbach G. Internet-Based Caregiver Support for Chinese Canadians Taking Care of a Family Member with Alzheimer Disease and Related Dementia. Canadian Journal of Aging. 2009; 28: 323-336.

[24] Lexis M. Activity monitoring technology to support homecare delivery to frail and psychogeriatric elderly persons living at home alone. Technology and Disability. 2013; 25: 189-197. doi: 10.3233/TAD-130377

[25] Beauchamp N, Irvine B, Seeley J, Johnson B. Worksite-based Internet multimedia program for family caregivers of persons with dementia. The Gerontologist. 2005; 45: 793-801. 
[26] Mahoney D, Mutschler P, Tarlow B, Liss E. Real World Implementation lessons and outcomes from the worker interactive networking (WIN) project: workplace-based online caregiver support and remote monitoring of elders at home. Telemedicine Journal and E-Health. 2008; 14: 224-234. doi: 10.1089/tmj.2007.0046

[27] Kuhn D, Hollinger-Smith L, Presser J, Civian J, Batsch N. Powerful Tools for Caregivers Online: An Innovative Approach to Support Employees. Journal of Workplace Behavioral Health. 2008; 23: 51-69.

[28] Jarrold K, Yeandle S. A Weight off My Mind: Exploring the impact and potential benefits of telecare for unpaid caregivers in Scotland. University of Leeds and Caregivers Scotland. 2009. http//www.sociology.leeds.ac.uk/assets/files/Circle/ carers-scotland-report-dec-2009.pdf

[29] Employers for Carers. Caring at a Distance: bridging the gap study. Carers UK. 2011. https//www.employersforcarers.org/ resources/research/item/246-caring-at-a-distance-bridgingthe-gap.

[30] World Medical Association, Declaration of Helsinki - Ethical principles for medical research involving human subjects. http//www.wma.net/en/30publications/10policies/b3/. World Medical, Association, 2013.

[31] Rosenthal C, Martinn-Matthews A, Keefe J. Care management and care provision for older relatives amongst employed informal care-givers. Ageing \& Society. 2007; 27: 755-778.
[32] Alwin J, Öberg B, Krevers B. Support/services among family caregivers of persons with dementia - perceived importance and services received. International Journal of Geriatric Psychiatry. 2010; 25: 240-248. doi: 10.1002/gps.2328

[33] Starr M, Szebehely M. Working longer, caring harder - the impact of 'ageing-in-place' policies on working carers in the UK and Sweden. International Journal of Care And Caring. 2017; 1(1): 115-119.

[34] Eldh AC, Carlsson E. Seeking a balance between employment and the care of an ageing parent. Scandinavian Journal of Caring Sciences. 2011; 25: 285-293.

[35] April BCG. Boessen, Renée Verwey, Saskia Duymelinck, and Erik van Rossum, An Online Platform to Support the Network of Caregivers of People with Dementia, Journal of Aging Research, vol. 2017, Article ID 3076859, 7 pages, 2017. doi: $10.1155 / 2017 / 3076859$

[36] Holst G, Edberg A. Wellbeing among people with dementia and their next of kin over a period of 3 years. Scandinavian Journal of Caring Sciences. 2011; 25: 549-557. doi: 10.1111/j.1471-6712.2010.00863.x

[37] Field A. Discovering statistics using IBM SPSS statistics: and sex and drugs and rock ' $n$ ' roll 4. ed., Los Angeles: London: Sage, 2013. 